\title{
The genus Neocyclops Gurney in the West Indies: an update including the description of Neocyclops (Protoneocyclops) geltrudeae n. sp. (Crustacea, Copepoda, Cyclopidae)
}

\author{
Amsterdam Expeditions to the West Indian Islands, Report 74*
}

\author{
Giuseppe L. Pesce \& Diana P. Galassi \\ Dipartimento di Scienze Ambientali, Università di L'Aquila, Via Vetoio, 67010 L'Aquila, Italy
}

Keywords: Taxonomy, Copepoda Cyclopidae, Neocyclops, interstitial marine fauna, West Indies

\begin{abstract}
Neocyclops (Protoneocyclops) geltrudeae n. sp. is described from the marine interstitial of Curaçao. Neocyclops (Neocyclops) medius Herbst, 1955 and $N$. (Neocyclops) vicinus Herbst, 1955 are for the first time recorded from the West Indies. New localities for Neocyclops (Protoneocyclops) stocki Pesce, 1985 from the West Indies are reported.
\end{abstract}

\section{Résumé}

On décrit Neocyclops (Protoneocyclops) geltrudeae n. sp. des eaux interstitielles marines de l'île de Curaçao. Neocyclops (Neocyclops) medius Herbst, 1955 et Neocyclops (Neocyclops) vicinus Herbst, 1955 sont signalés pour la première fois des Antilles. Des localités antillaises nouvelles pour Neocyclops (Protoneocyclops) stocki Pesce, 1985 sont rapportées.

\section{Introduction}

In a collection of cyclopoid copepods from different groundwater habitats of West Indian Islands, entrusted to us through the kindness of Prof. Dr. J.H. Stock and Dr. L. Botosaneanu (Amsterdam), four interesting species of the genus Neocyclops Gurney, 1927 were present, viz. Neocyclops (Neocyclops) medius Herbst, 1955, Neocyclops (Neocyclops) vicinus (Herbst, 1955), both for the first time recorded from the Caribbean region, Neocyclops
(Protoneocyclops) stocki Pesce, 1985, previously recorded from Bonaire (Pesce, 1985), Bermuda, St. Andres, and Cuba (Petkovski, 1986), and a new species from Curaçao, described herein as Neocyclops (Protoneocyclops) geltrudeae n. sp.

The discovery of these taxa in the West Indies brings the total number of species of the genus Neocyclops in the Caribbean up to seven, the others being $N$. improvisus** Pleşa, 1973 from Cuba, and $N$. (Neocyclops) affinis (Pleşa, 1961) and N. (Protoneocyclops) papuensis Fiers, 1986, both from the Bahamas (Fiers, in litt.).

According to Petkovski (1986), N. (Protoneocyclops) mediterraneus (Kiefer, 1960), reported from Cuba by Pleşa (1981), is in fact $N$. (Protoneocyclops) stocki Pesce, 1985.

The type material is preserved in the collections of the Zoölogisch Museum, Amsterdam, The Netherlands (ZMA) and in the zoological collections of the "Dipartimento di Scienze Ambientali", University of L'Aquila, Italy (GPC).

The following abbreviations are used throughout the text and figures: $\mathbf{A} 1=$ antennula; $\mathbf{A} 2=$ antenna; P1-P6 = 1st to 6th legs.

\section{Taxonomic part}

Family Cyclopidae G.O. Sars, 1913

Subfamily Halicyclopinae Kiefer, 1927

Genus Neocyclops Gurney, 1927

* Report 73 is published in Beaufortia, 41(11): 75-81 (1990).

* The subgeneric status of this species is unknown since it was described only on female specimens, while Petkovski (1986) established the subgenera Neocyclops and Protoneocyclops according to the articulation of the male P5. 
Subgenus Neocyclops Petkovski, 1986

Neocyclops (Neocyclops) medius Herbst, 1955

\begin{abstract}
Material. - Amsterdam Expeditions to the West Indian Islands: Sta. 82/05, Tortuga, Pta. Arenas, El Larenero (10 $53^{\prime} 54^{\prime \prime} \mathrm{N}$ $65^{\circ} 14^{\prime} 43^{\prime \prime}$ W), 18 February 1982, coll. J.H. Stock \& N. Broodbakker: $5 \%$ \& Sta. 82/14, Blanquilla, Falucho, surf zone $\left(11^{\circ} 49^{\prime} 27^{\prime \prime} \mathrm{N} 64^{\circ} 36^{\prime} 10^{\prime \prime} \mathrm{W}\right), 20$ February 1982 , coll. J.H. Stock \& J. Notenboom: 10 \% . Sta. 82/55, Los Roques, Dos Mosquises, E. coast, end of air strip, intertidal $\left(11^{\circ} 48^{\prime} 14^{\prime \prime} \mathrm{N}\right.$ 66 $53^{\prime} 25^{\prime \prime}$ W), 5 March 1982, coll. J.H. Stock \& S. Weinberg: 2 \& . Sta. 82/18, Margarita, beach of Puerto Viejo, $1 \mathrm{~km} \mathrm{~N}$. of Pietro Coszaleck ( $\left.11^{\circ} 07^{\prime} 40^{\prime \prime} \mathrm{N} 63^{\circ} 55^{\prime} 16^{\prime \prime} \mathrm{W}\right), 21$ February 1982, coll. L. Botosaneanu: $1 \propto \sigma$. Sta. 84/226, Bonaire, shore Lac near Sorobon, behind Hotel ruins $\left(12^{\circ} 05^{\prime} 53^{\prime \prime} \mathrm{N}\right.$ $68^{\circ} 14^{\prime} 02^{\prime \prime}$ W), 11 June 1984, coll. J.H. Stock \& J.J. Vermeulen: 10 .
\end{abstract}

Remarks. - The present material equals the original description of $N$. (N.) medius by Herbst (1955) in nearly all aspects. Some negligible differences were noticed in the morphology of the P5, which is more slender and elongated and in the P4, which has a more strongly developed apical spine on the distal segment of the endopodite.

Up to now, $N$. ( $N$.) medius was only known from two localities along the Brazilian Atlantic Coast (Herbst, 1955; Lotufo \& Da Rocha, 1993). The present collection clearly demonstrates that $N$. (N.) medius is widespread throughout the West Indian islands.

\section{Neocyclops (Neocyclops) vicinus (Herbst, 1955)}

Syn. - Pareuryte vicina Herbst, 1955.

Neocyclops vicinus; Lotufo \& Da Rocha, 1993.

Material. - Amsterdam Expeditions to the West Indian Islands: Sta. 82/51, Los Roques, Bekebe, leeward side, in seawater seeping through beach barrier ( $\left.11^{\circ} 51^{\prime} 22^{\prime \prime} \mathrm{N} 66^{\circ} 56^{\prime} 02^{\prime \prime} \mathrm{W}\right), 4 \mathrm{March}$ 1982, coll. J.H. Stock \& S. Weinberg: 1 \&. Sta. 82/118, Jamaica, Discovery Bay (Parish of St. Ann), near pumphouse of Marine Laboratory, about $15 \mathrm{~m}$ from the sea $\left(18^{\circ} 27^{\prime} 28^{\prime \prime} \mathrm{N}\right.$ $77^{\circ} 24^{\prime} 31^{\prime \prime}$ W), 22 March 1982, coll. J.H. Stock: 2 ९ .

Remarks. - Our material agrees in nearly all aspects with the original description of Pareuryte vicina by Herbst (1955) from Brazil. Differences of little systematic value are visible in the length ratio between the inner and the outer apical furcal setae, and in the more robust appearance of the vestigial A2 exopodite.

As far as we know, $N$. (N.) vicinus is recorded here for the first time from the West Indies (Los Roques, Jamaica). The presence of this species in the Black Sea (Pleşa, 1963; Monchenko, 1975; both as Eurycyclops remanei vicinus) is biogeographically disconcerting and needs future verification. Moreover, its presence in Cuba (Dussart \& Defaye, 1985; Reid, 1990) is considered now as erroneous (Dussart, in litt.; Reid, in litt.).

\section{Subgenus Protoneocyclops Petkovski, 1986}

\section{Neocyclops (Protoneocyclops) geltrudeae n. sp.} (Figs. 1-13)

Material. - Amsterdam Expeditions to the West Indian Islands: Sta. 84/86, Curaçao, Santa Marta Bay, inner bay, behind Field Lab. $\left(12^{\circ} 16^{\prime} 19^{\prime \prime} \mathrm{N} 69^{\circ} 07^{\prime} 37^{\prime \prime} \mathrm{W}\right)$, Bou-Rouch pump, probe at $80 \mathrm{~cm}$ below substrate surface. Substrate: coral debris and sand, 2 May 1981, coll. J.H. Stock \& J.J. Vermeulen: 1 ९ (holotype), dissected and mounted in Faure's medium (slide labelled Ne. 012) (GPC), 1 \% (paratype), mounted as above (slide labelled Ne. 013) (GPC), 2 ९ \& (paratypes), mounted as above (ZMA).

Description. - Female. Habitus with typical cyclopoid shape; length, excluding A1 and furcal setae, 0.740-0.850 mm; holotype $0.765 \mathrm{~mm}$; cephalothorax with largest width at posterior margin; genital segment about as long as wide; anal operculum slightly convex.

A1: 11-segmented, reaching towards middle of cephalothorax; aesthetascs implanted on 8th and 11 th segments; remaining ornamentation arranged as illustrated in Fig. 4. A2: basipodite with two naked setae inserted on the anterior caudal margin, one long plumose seta (vestigal exopodite) inserted on the posterior surface ("usual status", according to Reid, 1991), and a short proximal row of minute teeth at the posterior proximal corner; endopodite segments 1-3 with 1,5 , and 6 setae, respectively.

Mandible (Fig. 2): gnathobasis with strong teeth, additional short spines and 2 feathered setae; palp minute, bearing 3 setae of different lengths, outer one the longest. Other mouthparts without particular characteristics. Maxilla 2 illustrated (Fig. 3). 

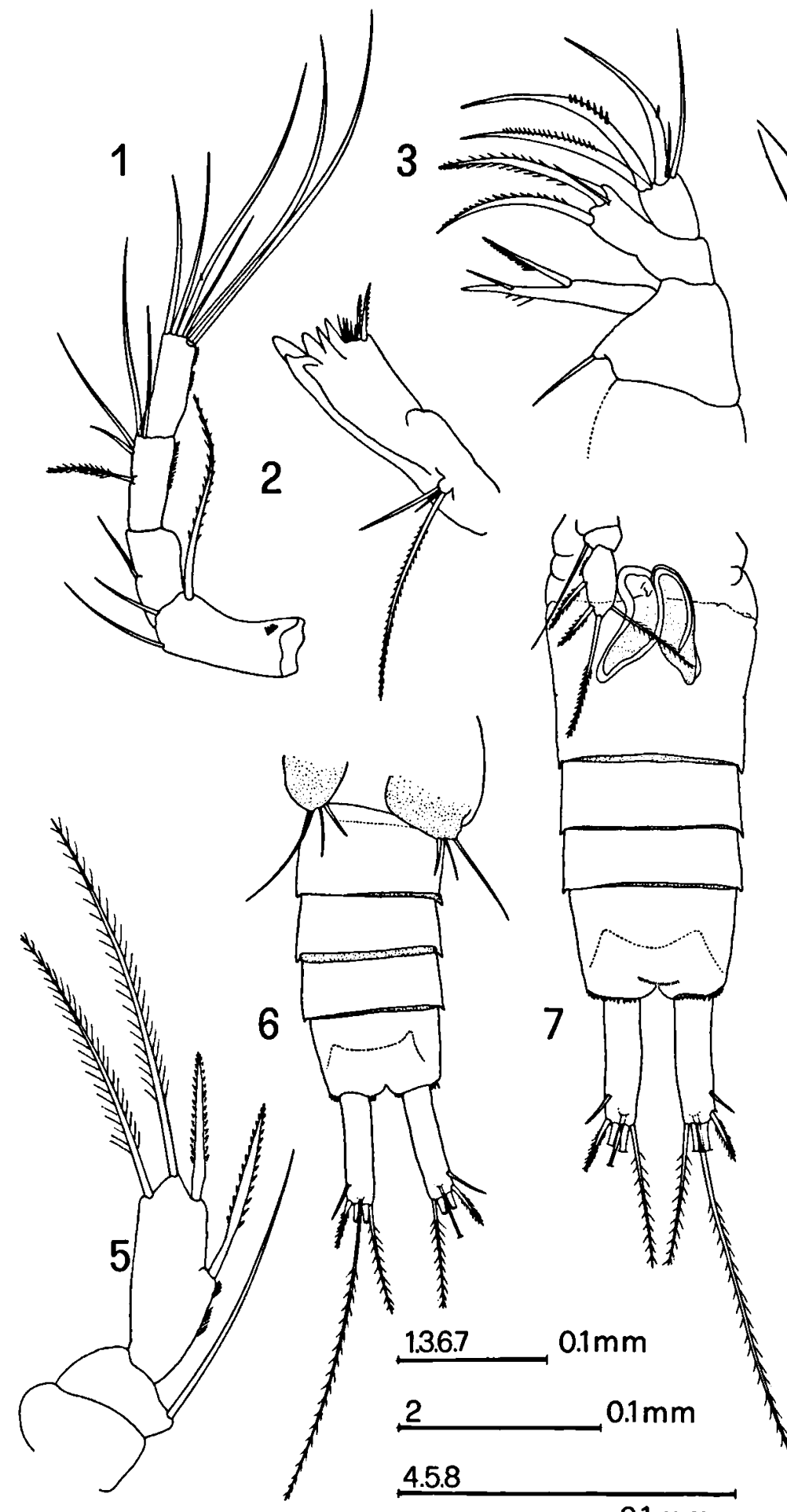

4
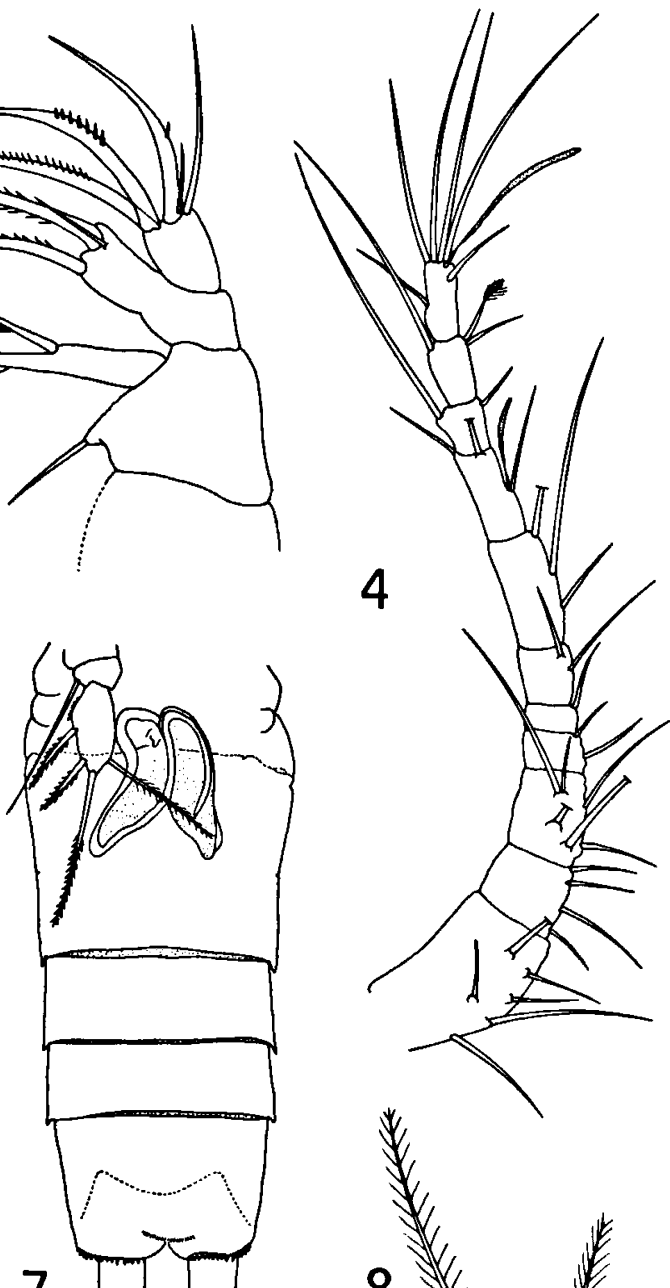



Figs. 9-13. Neocyclops (Protoneocyclops) geltrudeae n. sp. ( 9 holotype): 9, P1; 10, P4; 11, P3; 12, P2, endopodite; 13, P2, exopodite.

P1-P3 (Figs. 9, 11-13) with 3-segmented exopodites and endopodites; P4 with 2-segmented endopodite and 3-segmented exopodite. Spine formula of exopodite of P1-P4: 3.4.4.3. Coxa-basipodites and couplers of legs 1-4 and armature of P1-P3 without particular characteristics.

P4 (Fig. 10): basal and middle segment of exopodite each with 1 outer spine and 1 inner feathered seta, distal segment with 3 spines and 5 long, modified (plumose proximally and finely serrate distally) setae; basal segment of endopodite with 1 inner seta, second segment with 4 spines and 3 setae; ornamentation of the setae on the second segment of the endopodite typical, with setules along the proximal parts of the stems and finely spinulose on the more distal part.

P5 (Fig. 5): coxa lacking setation; basis with 1 outer smooth seta; exopodite subovoid, with 1 apical plumose, 2 outer spinulose and 1 inner plumose setae. 
Spermatophores as illustrated in Fig. 7.

Furcal rami (Fig. 7) 3.9-4.0 times as long as wide; lateral seta implanted in distal third of external margin; outer apical furcal seta spiniform; inner apical furcal seta longer $(2.50-2.55: 1)$ than outer one; dorsal seta very long, over 3 times as long as furcal ramus; median setae long, inner one longest and over 4 times as long as furcal ramus.

Male. - Habitus similar to the female; length, $0.630 \mathrm{~mm}$. P4 with both exopodite and endopodite 3-segmented. P5 (Fig. 8): basis with 1 outer seta (broken); exopodite 2-segmented, first segment with 1 inner seta and 1 outer spine, distal segment with 1 medial seta, 1 outer spine, and 2 inner setae. P6 consisting of large plate bearing 1 inner spine and 2 outer setae (Fig. 6 ). Other characteristics as in the female.

Etymology. - The species is dedicated to Dr. Geltrude Chiappini, member of our Department, who contributed to the present study.

Discussion. - Neocyclops (Protoneocyclops) geltrudeae $\mathrm{n}$. sp. is related to Neocyclops improvisus Pleşa, 1973, known from Cuba and Neocyclops (Protoneocyclops) papuensis Fiers, 1986, described from Papua New Guinea and recently found in the Bahamas (Fiers, in litt.). N. (P.) geltrudeae and $N$. improvisus share an 11-segmented antennula, as a result of the fusion between the original third and fourth segments. With $N$. (P.) papuensis, the present species shares the mandibular palp with 3 setae, the 2-segmented endopodite of female P4, as well as the identical morphology of the P1-P3. Furthermore, both species show the same ornamentation along the inner endopodal setae (Fiers, in litt.).

The new species differs from $N$. improvisus by several characteristics: the presence of a vestigial exopodal seta on the basipodite of the A2 (vs. absence), the 2-segmented endopodite of the female $P 4$, the length and armature of the furcal rami, the shape of the setae/spines of the female P5 and the armature of the male P5. It differs from $N$. (P.) papuensis by the different ornamentation of the spines/setae in the $\mathrm{P} 4$ [the proximal endopodal seta is setulose in $N$. (P.) papuensis, setulose/spinulose in the new species], the different number and shape of the setae/spines on the distal segment of the male P5, the different length ratio between the inner apical furcal seta and the outer apical furcal seta and, finally, the considerably longer dorsal furcal seta.

$N$. (P.) geltrudeae $\mathrm{n}$. $\mathrm{sp}$. is easily distinguished from its other congeners by the peculiar armature of the male P5 and the remarkably long furcal dorsal seta.

Neocyclops (Protoneocyclops) stocki Pesce, 1985

Material. - Amsterdam Expeditions to the West Indian Islands: Sta. 84/214, Bonaire, Plantation Bolivia, well near cave named "Spelonk" (12 $\left.13^{\prime} 23^{\prime \prime} \mathrm{N} 68^{\circ} 13^{\prime} 12^{\prime \prime} \mathrm{W}\right), 2$ June 1984, coll. J.H. Stock \& J.J. Vermeulen: 2 ९ . Sta. 84/103, Curaçao, St. Michiel Inner Bay; sand and coral debris, 25 May 1984, coll. J.H. Stock \& J.J. Vermeulen: 2 \% ९. Sta. 84/133, Curaçao, Kennedy Boulevard, coral rubble, intertidal, 30 May 1984, coll. J.H. Stock \& J.J. Vermeulen: 1 o .

Remarks. - Pesce (1985) described Neocyclops (Protoneocyclops) stocki from groundwaters (wells) of Bonaire. Later on the species was recorded from St. Andres and Bermuda (Petkovski, 1986), while some Neocyclops sp. reported by Pleşa (1981) from Cuba were identified as Neocyclops (Protoneocyclops) stocki by Petkovski (1986).

The present data from Bonaire and Curaçao enlarge the distribution of this species in the West Indies, showing that it is widespread in the Caribbean.

Key to females of species of Neocyclops from the Caribbean

1. A1, 11-segmented $\ldots \ldots \ldots \ldots \ldots \ldots \ldots \ldots \ldots \ldots \ldots \ldots \ldots 2$

- A1, 12-segmented ........................ 3

2. Al without vestigial exopodal seta; endopodite of P4,

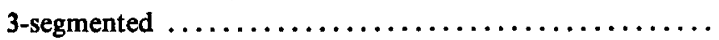
...................... improvisus Pleşa, 1973

- A1 with vestigial exopodal seta; endopodite of P4, 2-segmented ................. (P.) geltrudeae n. sp.

3. Endopodite of P4, 2-segmented $\ldots \ldots \ldots \ldots \ldots \ldots \ldots \ldots$ ........................ (P.) papuensis Fiers, 1986

- Endopodite of P4, 3-segmented or with segments 2 and 3 partially fused $\ldots \ldots \ldots \ldots \ldots \ldots \ldots \ldots \ldots \ldots \ldots \ldots$

4. Inner apical furcal seta longer than outer one $\ldots \ldots \ldots .5$ 
- Inner apical furcal seta slightly shorter or as long as outer

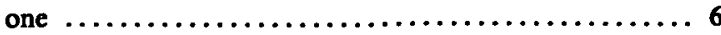

5. Inner apical furcal seta more than twice as long as outer one; dorsal seta more than twice as long as furcal ramus ......

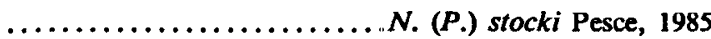

- Inner apical furcal seta slightly longer than outer one; dorsal seta about as long as furcal ramus ................

N. (N.) medius Herbst, 1955

6. Furcal rami about 2 times longer than wide; mandibular palp absent N. (N.) affinis (Pleşa, 1961)

- Furcal rami about 3 times longer than wide; mandibular palp present

N. (N.) vicinus (Herbst, 1955)

\section{Acknowledgements}

We are much indebted to Prof. Dr. J.H. Stock and Dr. L. Botosaneanu (Amsterdam) for the loan of material, to Dr. F. Fiers (Brussels) for precious assistance and information about the surprising finding of Neocyclops (Protoneocyclops) papuensis in the Bahamas, and to Dr. T.K. Petkovski (Skopje) for useful suggestions.

\section{References}

Dussart, B.H. \& D. Defaye, 1985. Répertoire mondial des Copépodes Cyclopoides: 1-236 (C.N.R.S., Paris).

Fiers, F., 1986. New and interesting copepods (Crustacea, Copepoda) from brackish waters of Laing Island (Northern Papua New Guinea). Léopold III Biological Station, Laing Island - Contribution $n^{\circ}$ 96. Bull. Inst. roy. Sci. nat. Belg., 56: 99-120.

Herbst, H.V., 1955. Cyclopoida Gnathostoma (Crustacea Copepoda) von der brasilianischen Atlantikküste. Kieler Meeresforsch., 11(2): 214-229.

Lotufo, G.R. \& C.E.F. da Rocha, 1993. Neocyclops Gurney from Brazilian sandy beaches (Copepoda: Cyclopoida). Bijdr. Dierk., 63(3): 163-172.

Monchenko, V.I., 1975. Eurycyclops (Crustacea, Copepoda) in fauna of the Soviet Union. Dokl. Akad. Nauk., Ukr. SSR, (B) 1975(5): 471-477.

Pesce, G.L., 1985. Cyclopids (Crustacea, Copepoda) from West Indian groundwater habitats. Bijdr. Dierk., 55(2): 295-323.

Petkovski, T.K., 1986. Zur Taxonomie des Genus Neocyclops Gurney, 1927 (Crustacea, Copepoda, Cyclopoida). Acta Mus. maced. Sci. nat. Skopje, 18(2/148): 27-46.

Pleșa, C., 1961. New cyclopoids (Crustacea, Copepoda) of the interstitial fauna from the beaches of Ghana. J. West Afr. Sci. Ass., 7(1): 1-13.

Pleşa, C., 1963. Étude sur la faune interstitielle littorale de la Mer Noire, III. Résultats préliminaires des recherches sur la côte roumaine, avec aperçue spécial sur les Cyclopoïdes Gnathostomes (Crustacea, Copepoda). Vie Milieu, 14(4): 775-814.

Pleşa, C., 1973. Un nouveau Cyclopide interstitiel de la Mer des Caraỉbes: Neocyclops improvisus n. sp. (Crustacea, Copepoda). Résultats des Expéditions biospéologique cubano-roumaines à Cuba, 1: 119-122 (Ed. Acad. Rep. Soc. România).

Pleşa, C., 1981. Cyclopoïdes (Crustacea, Copepoda) de Cuba. Résultats des Expéditions biospéologiques cubano-roumaines à Cuba, 3: 17-34 (Ed. Acad. Rep. Soc. România).

Reid, J.W., 1990. Continental and coastal free-living Copepoda (Crustacea) of Mexico, Central America and the Caribbean region. In: D. Navarro L. \& J.G. Robinson (eds.), Diversidad biologica en la Reserva de la Biosfera de Sian Ka'an, Quintana Roo, México: 175-213 (Centro de Investigaciones de Quintana Roo \& Program of Studies in Tropical Conservation, University of Florida; printed and published at Chetumal, Quintana Roo).

Reid, J.W., 1991. Use of fine morphological structures in interpreting the taxonomy and ecology of continental cyclopoid copepods (Crustacea). Anais do IV Encontro Brasileiro de Plancton: 261-282.

Received: 2 November 1992

Revised: 13 May 1993 